\title{
Evolution, growth and phenology of Phalaris minor biotypes resistant to ACCase-inhibiting herbicides in Mexico
}

\section{cc creative \\ commons}

Botanical Sciences

96 (1): 95-102, 2018

DOI: $10.17129 /$ botsci.1338

Received:

April 7th, 2017

Accepted:

October 2nd, 2017

Associated Editor:

Juan Núñez Farfán

This is an open access article distributed under the terms of the Creative Commons Attribution License, which permits unrestricted use, distribution, and reproduction in any medium, provided the original author and source are credited.

1 Postgrado en Botánica, Colegio de Postgraduados, Montecillo, Edo. de México, Mexico.

${ }^{2}$ Laboratorio de Genética Ecológica y Evolución, Departamento de Ecología Evolutiva, Instituto de Ecología, Universidad Nacional Autónoma de México, Ciudad de México, Mexico.

${ }^{3}$ Postgrado en Entomología y Acarología, Colegio de Postgraduados, Edo. de México, Mexico.

${ }^{4}$ Escuela de Biología, Benemérita Universidad Autónoma de Puebla, Puebla, Mexico.

*Corresponding author: euscanga@colpos.mx
Jesús Rubén Torres-García ${ }^{1,2}$, Obdulia Segura-León 3 , Ebandro UscangaMortera ${ }^{1 *}$, Carlos Trejo ${ }^{1}$, Víctor Conde-Martínez ${ }^{1}$, Josúe Kohashi-ShlBATA $^{1}$ AND DAVID MarTíneZ-MORENO ${ }^{4}$

\section{Abstract}

Background: Herbicide application to control weeds can promote a rapid selection of resistant phenotypes in small geographic areas. Also, in areas with a spatial heterogeneous management, resistance may evolve independently, promoting local adaptation in weeds. In the mexican region known as "El Bajio," 100,000 ha are cultivated with wheat, and the weed Phalaris minor, resistant to ACCase-inhibiting herbicides is commonly present.

Question: We aim to identify the population structure of two genes in four different P. minor biotypes from "El Bajio" and to determine their association with phenology and plant growth differences (biomass and seed yield) that may contribute to survival in the agricultural environment.

Studied species: Phalaris minor Retz.

Study site and years of study: The study was carried out at a greenhouse and at the molecular biology laboratory of the Colegio de Postgraduados, during 2013 and 2014.

Methods: The diversity of the $p s b A$ gene and the sequence of two ACCase gene fragments as well as phenology, growth and biomass allocation were evaluated.

Results: Results indicated different polymorphism levels for the two genes. There were no differences in the $p s b A$ gene between biotypes, although the ACCase gene exhibited high polymorphism level. In addition, each biotype showed differences in phenology, biomass accumulation and fecundity.

Conclusions: The ACCase-inhibiting herbicide resistance in "El Bajio" region might be a resistance hotspot leading to the local adaptation of weeds.

Key words: Evolution, herbicide resistance, local adaptation.

\section{Resumen}

Antecedentes: La aplicación de herbicidas para el control de las malezas puede fomentar una rápida selección de fenotipos resistentes en áreas geográficas pequeñas. También, en áreas con un manejo heterogeneo espacial, la resistencia puede evolucionar independientemente, promoviendo adaptaciones locales de las malezas. En la region mexicana conocida como "El Bajío", se cultivan 100,000 ha con trigo, y la maleza Phalaris minor, resistente a herbicidas inhibidores de la ACCasa está comunmente presente.

Pregunta: El objetivo fue identificar la estructura poblacional de dos genes en cuatro biotipos diferentes de P. minor de "El Bajío" y determinar su asociación con las diferencias en fenología y crecimiento de la planta (biomasa y rendimiento de semilla) que puedan contribuir a la sobrevivencia en campos agrícolas .

Especie estudiada: Phalaris minor Retz.

Sitio y años de estudio: El estudio se realizó en un invernadero y en el laboratorio de Biología Molecular del Colegio de Postgraduados durante 2013 y 2014.

Métodos: La diversidad del gen $p s b A$ y la secuencia de dos fragmentos del gen ACCasa fueron evaluados, así como también la fenología, el crecimiento y la asignación de biomasa.

Resultados: Los resultados indicaron diferentes niveles de polimorfismo para los dos genes. No hubieron diferencias en el gen $p s b A$ entre los biotipos, aunque el gen ACCasa exhibió nivel alto de polimorfismo. Además, cada biotipo mostró diferencias en la fenología, acumulación de biomasa y fecundidad.

Conclusiones: La resistencia a herbicidas inhibidores de la ACCasa en la region de "El Bajío" puede ser debida a parches que conducen a adaptaciones locales de las malezas.

Palabras clave: Adaptación local, evolución, resistencia a herbicidas. 
he application of systemic herbicides to control weeds exerts intense selection pressure on weed populations (up to $99.99 \%$ ) (Maxwell et al. 1990), and the extensive application of herbicides with the same mode of action selects for mutations at the site of action or changes plant metabolism that allows plants to resist these herbicides (Powles \& Yu 2010). The intense selection pressure reduces the effective plant population size to only few resistant individuals. The continued use of the same herbicide on each generation increases the number of resistant individuals that can outcompete susceptible individuals (Maxwell et al. 1990).

Weed populations in neighboring geographic areas can evolve relatively quickly to herbicide resistance (Baucom \& Holt 2009), because crop management depends on farmer decisions, like timing, doses, and the number of applications as well as the kind of herbicide applied (Délye et al. 2004, Owen et al. 2011), herbicide resistance might occur independently among cultivars. For example, in localities in close spatial proximity, such as in the case of Alopecurus myosuroides Huds. in Europe (Délye et al. 2004, Délye et al. 2010). Further, the cultural practices that include the sharing of equipment and seeds, along with seed and pollen dispersal, enable resistant biotypes to disperse over large areas (Afentouli \& Eleftherohorinos 1996).

Such scenario is likely in the central region of Mexico known as "El Bajio" $\left(20^{\circ} 25^{\prime} \mathrm{N} 101^{\circ}\right.$ $38^{\prime} \mathrm{W}$ ), where ca. 100,000 ha are cultivated with wheat although individual farmers cultivate parcels of ground 1-2 ha. Here, Phalaris minor Retz. is the main problem in wheat cultivation. P. minor (Poaceae) is an Asian weed dispersed worldwide. This weed is considered as one of the worst weed for wheat production (Afentouli \& Eleftherohorinos 1996). This plant has an erect habit with stems up to $180 \mathrm{~cm}$ tall, its leaves are long, linear and acuminate. The inflorescences are panicules that produces a high amount of seeds. The principal way of dispersion is through the seed. The seeds of $P$. minor is around $2 \mathrm{~mm}$ of length and $1.7 \mathrm{mg}$ of weight. Each plant can produce around 5,000 or even more seeds, depending the number of spikelets produced (Shukla 1996).

Since 1996, biotypes resistant to ACCase-inhibiting herbicides have been reported on at least 100 farms, affecting approximately 5,000 ha (Heap 2016). Using dose response tests, the presence of resistant $P$. minor populations has been documented in at least four sites (Tafoya \& Morgado 2000).

Because of the geographic distance between sites and differences in crop management, each site might constitute a hot spot of herbicide resistance evolution. Furthermore, each resistant biotype might be locally adapted (life cycle and physiology) as a result of selection imposed by agricultural practices (Weinig 2005). For the biotypes present in this zone, some studies have shown differences in the early stages of plants life history, including changes in seed physiology (germination rate, dormancy and longevity) and growth for canopy competition (Torres-García et al. 2015a, 2015b). In addition, empirical evidence based on morphology suggests differentiation among resistant weed populations (García-Franco et al.2014). To date, the molecular basis of herbicide resistance and the biological characteristics of P. minor populations at "El Bajio" have not been yet described.

We hypothesize that $P$. minor biotypes encode different polymorphisms in the gene that confers resistance to herbicides (ACCase) as well as in a non-related gene ( $p s b A)$. Furthermore, the biotypes should exhibit differences in phenology, growth rates, and reproductive output derived from farmers' management practices. In this study, we aim to determine 1) if the genes $p s b A$ and ACCase from P. minor biotypes from the "El Bajio" show polymorphisms associated with herbicide resistance selection, and 2) to what extent it leads to differences in phenology and growth (biomass and seed yield) that allow survival in the agricultural environment.

\section{Materials and methods}

physiological variables to take and make the interpretation.

Víctor Conde Martínez helped to write the paper.

Josué Kohashi Shibata make a critical reviewed and suggested changes on the paper.

David Martínez Moreno helped to analyze the data.

A collection of at least 20 populations of $P$. minor reported to be resistant (R) to clodinafoppropargyl was generated in "El Bajio," Mexico (20 25' N 101 $\left.38^{\circ} \mathrm{W}\right)$. One biotype from a location $85 \mathrm{~km}$ further apart, where the plants grew outside crops never subjected to chemical control (personal communication of farmers) was used as the susceptible line (Figure 1). Doseresponse resistance were performed for each population. Potential resistance of each biotype was determined in Petri dishes with agar gel containing clodinafop-propargyl $\left(20 \mathrm{~mL} \mathrm{~L}^{-1}\right)$ (Tal et al. 2000). The four biotypes with the highest herbicide resistance were selected: $\mathrm{Col} 4, \mathrm{Col} 7$, 
Figure 1. Geographic localities where biotypes of Phalaris minor were sampled in "El Bajio," Mexico.

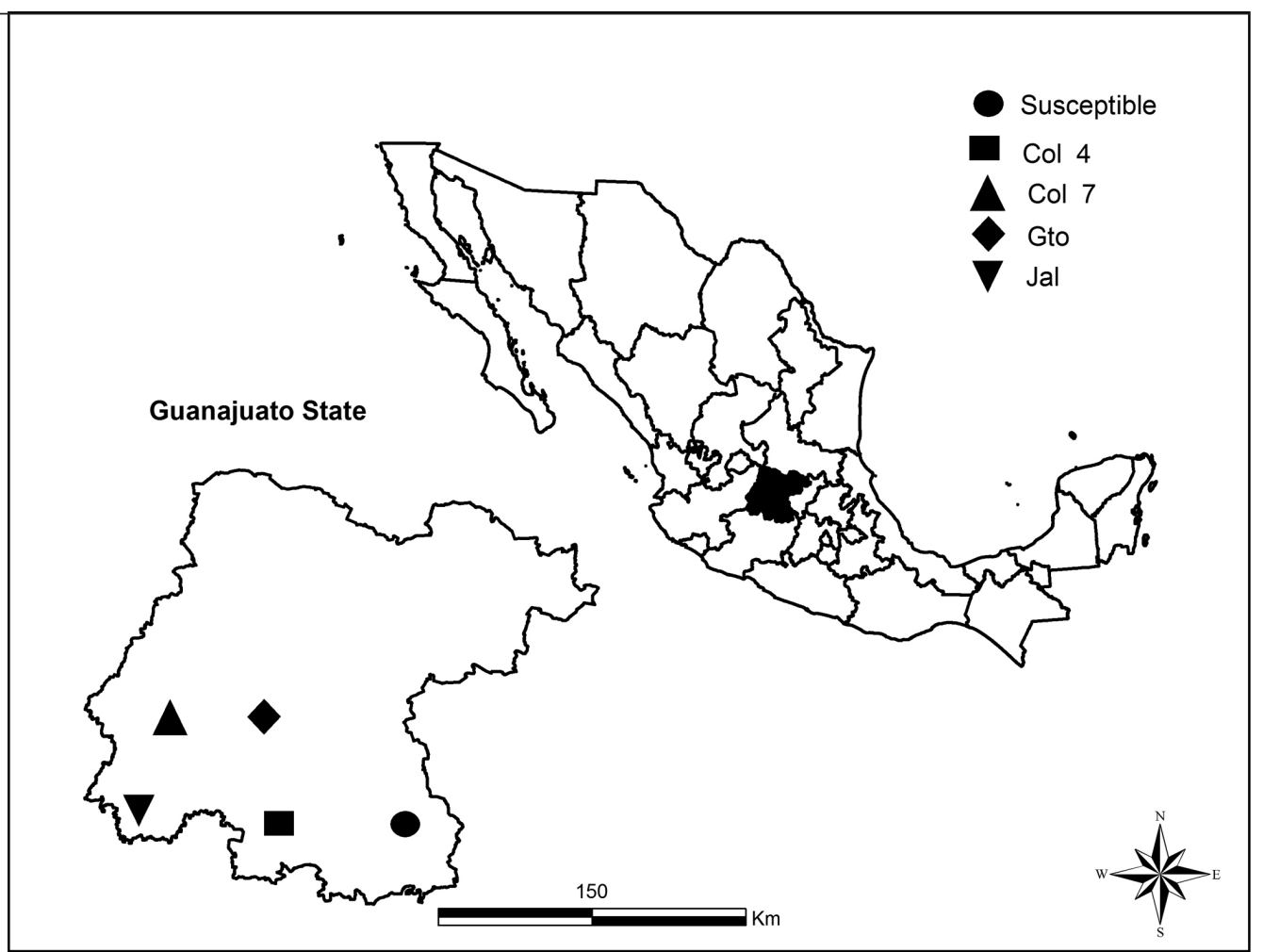

Gto and Jal. A dose response test was performed on these biotypes in a greenhouse to determine if these resist to field doses of herbicide application. The biotypes $\mathrm{Col} 4, \mathrm{Col} 7$ and Gto survived in doses 12-fold higher than the field dose, whereas the Jal biotype showed 6.8-fold resistance in relation to the susceptible line.

Seedlings of the selected biotypes were grown in pots. Twenty days after emergence, clodinafop-propargyl was applied at a rate of $120 \mathrm{~g}$ a.i. ha- $\mathrm{h}^{-1}$ to each population. Plants that survived herbicide applications were maintained to produce seeds. Seeds were stored in laboratory conditions and used in all further experiments reported here.

Molecular basis of resistance. Seeds of different biotypes were germinated and grown until the appearance of the first leaves. DNA was extracted from 5 individuals from each population. DNA extraction was performed using the CTAB method (Stewart \& Via 1993). To determine whether herbicide resistance in these biotypes was conferred by mutations at the site of action, two regions of the ACCase gene (from position 5,109 to 5,632 and 5,950 to 6,355) and psbA were amplified. Two sets of universal primers for ACCase that were developed by Délye \& Michel (2005) were used for amplification (Table 1). The PCR mix contained 1X buffer, $10 \mathrm{mM}$ dNTPs, $1 \mu \mathrm{L}$ DNA (50 ng $\mu \mathrm{L}^{-1}$ ), $1.5 \mathrm{mM} \mathrm{MgCl}_{2}, 1 \mathrm{U}$ Taq (Flexitaq; Promega), and $10 \mathrm{mM}$ each primer at a final volume of $25 \mu \mathrm{L}$. The amplification conditions were as follows: denaturation at $95{ }^{\circ} \mathrm{C}$ for $30 \mathrm{~s}$; followed by 37 cycles of $95^{\circ} \mathrm{C}$ for $10 \mathrm{~s}, 60$ or $61^{\circ} \mathrm{C}$ (depending on the fragment) for $15 \mathrm{~s}$, and $72{ }^{\circ} \mathrm{C}$ for $45 \mathrm{~s}$; followed by a final extension at $72{ }^{\circ} \mathrm{C}$ for $10 \mathrm{~min}$. Gene amplification was performed in a Biometra thermocycler (TPersonal model).

For psbA amplification, a P. minor sequence reported in GenBank (AY211527; Tal \& Rubin 2002, unpublished) was used for primer design. The primers were designed using Primer3 software (Untergasser et al. 2007) (Table 1). The PCR conditions were similar to those used for the ACCase gene, and the amplification program was as follows: $95{ }^{\circ} \mathrm{C}$ for $120 \mathrm{~s}$; followed by 30 cycles at $95{ }^{\circ} \mathrm{C}$ for $60 \mathrm{~s}, 52{ }^{\circ} \mathrm{C}$ for $30 \mathrm{~s}$, and $72{ }^{\circ} \mathrm{C}$ for $60 \mathrm{~s}$; and a final extension at $72{ }^{\circ} \mathrm{C}$ for 8 min. The PCR products were separated on $0.8 \%$ agarose gels in $1 \%$ TBA buffer at $76 \mathrm{~V}$ for 20 min. Positive amplicons were sequenced by Macrogen, Inc. (South Korea).

A sequence analysis was performed using MEGA (Molecular Evolutionary Genetic Analysis) software version 6 (Tamura et al. 2013). Prior to analysis, we confirmed the quality and 
Table 1. Name, sequence, fragment size (bp) and annealing temperature $\left({ }^{\circ} \mathrm{C}\right)$ of the primers used to amplify the ACCase gene (ACcp1, ACcp1R, ACcp4 and ACcp2R) (Delyé \& Michel 2005).

\begin{tabular}{llcc} 
Primer & Sequence $\left(\mathbf{5}^{\prime} \mathbf{-} \mathbf{3}^{\prime}\right)$ & $\begin{array}{c}\text { Fragment } \\
\text { size } \mathbf{( b p )}\end{array}$ & $\begin{array}{c}\text { Annealing } \\
\text { temperature }\left({ }^{\circ} \mathbf{C}\right)\end{array}$ \\
\hline psbA F & CTACCTTATTGACTGCAACT & 750 & 52 \\
psbA R & TTAGGTTGAAAGCCATAGT & & 52 \\
\hline ACcp1 & CAACTCTGGTGCTIGGATIGGCA & 523 & 60 \\
ACcp1R & GAACATAICTGAGCCACCTIAATATATT & & 60 \\
\hline ACcp4 & CAGCITGATTCCCAIGAGCGITC & 405 & 61 \\
ACcp2R & CCATGCAITCTTIGAGITCCTCTGA & 61 \\
\hline
\end{tabular}

effective size of the sequences included in the alignment. The sequences were aligned with the program Clustal W, and translation to amino acids was performed using the chloroplast genetic code. Each amplified region was analyzed independently. For the ACCase gene, the two fragments were linked, indicating the start and end site of each fragment. The alignment of each gene included a P. minor sequence from Israel that is reported in GenBank as susceptible to ACCase-inhibiting herbicides (AY196481, AY211527).

Evaluation of growth. To assess possible differences among herbicide-resistant populations, 40 seeds of each resistant biotype were sown in pots (1.7 L capacity) filled with forest soil and sand in a 2:1 ratio. The moisture of the substrate was maintained near field capacity throughout the entire experiment, which was performed in two seasons: autumn-winter (October through March) and spring-summer (April through August). The minimum and maximum daily temperatures in the greenhouse were recorded during the experiment. The number of growing degree days (GDD) was calculated according to Forcella \& Banken (1996): GDD $=[($ Tmax + Tmin) / 2]-Tbase. The base temperature for P. minor was estimated to be $10{ }^{\circ} \mathrm{C}$.

Phenology and accumulation of growing degree days. The phenological stages were recorded during the experiment. These stages included: emergence, the occurrence of the second and fourth leaf blades, the occurrence of the spike and the end of anthesis. It was assumed that each stage was achieved when $50 \%$ of the plants in each biotype exhibited the above-mentioned characteristics. We estimated the number of GDD between the phenological stage and subsequent stages.

Production and biomass allocation. At each phenological stage, 10 plants were destructively sampled to obtain dry matter. These plants were dissected into different structures (roots, culms, leaf blades, inflorescences and seeds). The organs were placed in paper bags and dried to a constant weight at $80^{\circ} \mathrm{C}$. The weight (g) of each organ was recorded to obtain the total biomass weight per plant. The dry matter percentage allocation for each organ was also determined. Finally, we counted the number of culms, leaf blades, tillers and spikes in each plant.

Growth analysis. We used the methodology proposed by Hunt (1978) to evaluate the absolute growth rate (AGR), relative growth rate (RGR), net assimilation rate (NAR) and leaf area duration (LAD). The LAD is usually expressed in days; however, because of the growth conditions in the greenhouse, we expressed this calculation in $\mathrm{dm}^{2} \mathrm{~d}^{-1}$ (Hunt 1978).

Statistical analysis. For the statistical analysis each biotype was considered as a treatment. In the harvests 10 replicates per biotype were used. The second variation factor was the growing season (autumn-winter and spring-summer). A completely randomized design was used in both growing seasons. To remove the seasonal effect, autumn-winter and spring-summer data were analyzed as a series of experiments in time, in which the growing season is nested within replicates (Cochran \& Cox 1990). A mixed model was used, the biotype was considered as a random factor and the season as fixed factor. Prior to statistical analyses, the percentages were transformed with the arcsine function, and after analyses, the data were transformed back to 
their original scale. Significant differences between the treatment means were identified with Tukey's multiple comparison test $(P<0.05)$.

\section{Results}

Molecular basis of resistance. Results from sequencing ACCase and $p s b A$ gene fragments showed different variation patterns among biotypes. The gene $p s b A$ showed no variation; and in the ACCase gene, we found 24 variable sites out of 752 analyzed nucleotides. Within each biotype, different number of variable sites were observed, and the biotype with more variable sites was Col 4 (16 sites), followed by Gto (14 sites), Col 7 (13 sites) and Jal (8 sites) (Table 2).

Table 2. Mutations in the site of action in Littleseed canarygrass biotypes resistant to ACCase-inhibiting herbicides in "El Bajio," Mexico (Col 4, Col 7, Gto and Jal).

\begin{tabular}{lccccc} 
& Sec & Hap & sites & Variable sites & Substitutions \\
\hline Susceptible & 5 & 5 & 752 & 14 & \\
Col 4 & 5 & 5 & 752 & 16 & 2041 Ile x Asn \\
Col 7 & 5 & 5 & 752 & 13 & 2078 Asp x Gly \\
Gto & 4 & 4 & 752 & 14 & 1781 Ile x Leu \\
Jal & 5 & 4 & 752 & 8 & 2027 Trp x Cys \\
\hline Total & $\mathbf{2 4}$ & $\mathbf{2 3}$ & $\mathbf{7 5 2}$ & $\mathbf{2 4}$ & \\
\hline
\end{tabular}

Abbreviations: Hap = haplotypes.

Translation of the DNA sequence to the amino acid sequence showed that not all the changes modified the protein structure, as most mutations were synonymous. The amino acid sequence of the S line was identical to that of Israel sequence labeled as susceptible to ACCase-inhibiting herbicides in GenBank (AY196481). All biotypes showed only one amino acid change compared to $\mathrm{S}$, and this change occurred at different positions in each biotype: Col 4 (2041 Ile $\mathrm{x}$ Asn), Col 7 (2078 Asp x Gly), Gto (1781 Ile x Leu) and Jal (2027 Trp x Cys).

Phenology and accumulation of growing degree days. The studied biotypes showed phenology differences during the experiment. The biotypes Col 7 and Jal exhibited a similar phenology and GDD accumulation, $163 \mathrm{~d}(3,265$ GDD) and $159 \mathrm{~d}(3,222 \mathrm{GDD})$, respectively (Table 3$)$. In contrast, the $\mathrm{Col} 4$ and Gto biotypes showed early development. Differences in among biotypes were observed since the first harvest, and become more evident at the end of the experiment. Flowering time in both $\mathrm{R}$ and $\mathrm{S}$ biotypes occurred at $90 \mathrm{~d}$ (1,851 GDD).

\begin{tabular}{|c|c|c|c|c|c|c|c|c|}
\hline \multirow[t]{2}{*}{ Biotype } & \multicolumn{2}{|c|}{ 2nd leaf blade } & \multicolumn{2}{|c|}{ 4th leaf blade } & \multicolumn{2}{|c|}{$\begin{array}{l}\text { Beginning } \\
\text { of flowering }\end{array}$} & \multicolumn{2}{|c|}{$\begin{array}{c}\text { Physiological } \\
\text { maturity }\end{array}$} \\
\hline & Days & GDD & Days & GDD & Days & GDD & Days & GDD \\
\hline Col 4 & $15 \pm 3$ & $306 \pm 28$ & $26 \pm 4$ & $522 \pm 41$ & $90 \pm 4$ & $1851 \pm 40$ & $140 \pm 4$ & $2892 \pm 38$ \\
\hline Col 7 & $15 \pm 3$ & $312 \pm 28$ & $40 \pm 5$ & $588 \pm 47$ & $134 \pm 7$ & $2720 \pm 67$ & $162 \pm 6$ & $3222 \pm 62$ \\
\hline Gto & $12 \pm 2$ & $247 \pm 18$ & $26 \pm 5$ & $522 \pm 49$ & $90 \pm 3$ & $1851 \pm 32$ & $143 \pm 7$ & $2926 \pm 68$ \\
\hline Jal & $18 \pm 4$ & $372 \pm 36$ & $37 \pm 4$ & $733 \pm 38$ & $121 \pm 6$ & $2502 \pm 55$ & $159 \pm 5$ & $3265 \pm 55$ \\
\hline
\end{tabular}

Production and distribution of biomass. In terms of biomass accumulation at physiological maturity, Jal showed the highest accumulation, followed by Col 7. In contrast, the biotypes with early growth ( $\mathrm{Col} 4$ and Gto) produced less biomass. Biomass allocation to different plant organs indicated that, in all of the biotypes, the highest fraction of biomass was allocated to roots (e.g., $49.2 \%$ in Col 7) followed by the culms, leaves and seeds. Biotypes with early growth showed a reduction in biomass allocation to roots of up to $20 \%$ with respect to $S$ biotype (Table 4).

With respect to the aerial biomass, Jal exhibited the greatest dry matter accumulation (culms, leaves and inflorescences). In contrast, Gto exhibited the lowest accumulation in these struc- 
Table 4. Dry biomass allocated to roots, culms, leaf blades and total biomass ( $\mathrm{g}$ plant ${ }^{-1}$ ) in Phalaris minor biotypes resistant to ACCase-inhibiting herbicides in "El Bajio," Mexico. Different letters indicate statistically significant differences.

\begin{tabular}{|c|c|c|c|c|c|c|c|c|c|c|c|}
\hline & \multicolumn{2}{|c|}{ Root } & \multicolumn{2}{|c|}{ Culm } & \multicolumn{2}{|c|}{ Leaf blades } & \multicolumn{2}{|c|}{ Spikes } & \multicolumn{2}{|c|}{ Seeds } & \multirow{2}{*}{$\begin{array}{c}\text { Total } \\
\mathrm{g} \\
\end{array}$} \\
\hline & g & $\%$ & g & $\%$ & g & $\%$ & g & $\%$ & g & $\%$ & \\
\hline Col 4 & $8.2 \pm 1.3$ b & $38.5 \pm 6.1 b$ & 6. $0 \pm 2.2 \mathrm{~b}$ & $28.2 \pm 10.3 \mathrm{ab}$ & $3.2 \pm 0.8 b$ & $15.0 \pm 3.8 \mathrm{~b}$ & $1.3 \pm 0.4 b$ & $6.1 \pm 1.9 \mathrm{a}$ & $2.6 \pm 0.5 \mathrm{ab}$ & $12.2 \pm 2.3 \mathrm{a}$ & $21.3 \mathrm{c}$ \\
\hline $\mathrm{Col} 7$ & $19.3 \pm 3.4 \mathrm{a}$ & $49.2 \pm 8.7 \mathrm{a}$ & $10.0 \pm 3.1 \mathrm{a}$ & $25.5 \pm 7.9 \mathrm{ab}$ & $7.2 \pm 1.2 \mathrm{a}$ & $18.4 \pm 3.1 \mathrm{ab}$ & $0.2 \pm 0.1 \mathrm{C}$ & $0.5 \pm 0.3 d$ & $2.5 \pm 0.3 \mathrm{ab}$ & $6.4 \pm 0.8 b$ & $39.2 b$ \\
\hline Gto & $5 \pm b 0.8$ & $31.8 \pm 5.1 \mathrm{~b}$ & $4.8 \pm 1.7 b$ & $30.6 \pm 10.8$ a & $3.2 \pm 0.4 \mathrm{~b}$ & $20.4 \pm 2.6 \mathrm{a}$ & $1.1 \pm 0.3 b$ & $7.0 \pm 1.9 \mathrm{~b}$ & $1.6 \pm 0.2 b$ & $10.2 \pm 1.3 \mathrm{a}$ & $15.7 d$ \\
\hline Jal & $21.2 \pm 3.2 \mathrm{a}$ & $46.5 \pm 7.0 \mathrm{a}$ & $11.0 \pm 2.0 \mathrm{a}$ & $24.1 \pm 4.4 b$ & $8.0 \pm 0.9 \mathrm{a}$ & $17.5 \pm 2 \mathrm{ab}$ & $2.4 \pm 0.5 \mathrm{a}$ & $5.3 \pm 1.1 \mathrm{a}$ & $3.0 \pm 0.4 \mathrm{ab}$ & $6.6 \pm 0.9 b$ & $45.6 \mathrm{a}$ \\
\hline $\begin{array}{l}\text { SIGINIFI- } \\
\text { CANCE }\end{array}$ & $* * *$ & $* * *$ & $* * *$ & $* * *$ & $* * *$ & $* * *$ & $* * *$ & $* * *$ & $* *$ & $* * *$ & $* * *$ \\
\hline $\begin{array}{l}\text { HSD (Tukey } \\
\text { test, } 0.05 \text { ) }\end{array}$ & 4.4 & 7.8 & 3.2 & 6.2 & 1.6 & 3.5 & 0.7 & 2.4 & 1.5 & 3.6 & 5.5 \\
\hline
\end{tabular}

tures (Table 4). The differences between biotypes were related to the number of culms, and leaves in biotypes with a long life cycle which had the greatest number of leaves and, therefore, the greatest leaf area (Table 4).

No difference among the biotypes $\mathrm{Col} 4, \mathrm{Col} 7$ and $\mathrm{Jal}$ in seed production $\left(\mathrm{g}\right.$ plant $\left.{ }^{-1}\right)$ were observed. The Gto biotype showed the lowest seed production per plant. However, biomass allocation showed a different trend; the short-cycle biotypes allocated more biomass matter to seeds than the long-cycle biotypes (Table 2). The increase in biomass allocation to seeds in the short-cycle biotypes occurred because flowering began $30 \mathrm{~d}$ earlier; therefore, these plants had more time for seed formation. This increase might also be a compensatory response, e.g., by decreasing the size of the plant, more dry matter can be allocated to seed production (reproductive effort).

Growth analysis. The growth rate exhibited a trend similar to that observed for biomass accumulation. The absolute and relative growth rates (AGR and RGR) were highest in the biotypes with the greatest biomass accumulation (Jal and Col 7) (Table 5). The RGR data showed that Jal and $\mathrm{Col} 7 \mathrm{had}$ the highest efficiency with respect to biomass production from existing biomass. No difference in NAR was found between biotypes. The LAD was greater in Col 7 and Jal than in $\mathrm{Col} 4$ and Gto, due to a higher biomass accumulation in leaves, a larger number of leaves and a greater leaf area.

Table 5. Growth analysis of Phalaris minor resistant to ACCase-inhibiting herbicides biotypes in "El Bajio," Mexico. Absolute growth rate (AGR), relative growth rate (RGR), net assimilation rate (NAR) and leaf area duration (LAD). Different letters indicate statistically significant differences.

\begin{tabular}{lllll} 
Biotypes & AGR & RGR & NAR & LAD \\
\hline & $\mathrm{g} \mathrm{d}^{-1}$ & $\mathrm{~g} \mathrm{~g}^{-1} \mathrm{~d}^{-1}$ & $\mathrm{~g} \mathrm{dm}^{-2} \mathrm{~d}^{-1}$ & $\mathrm{dm}^{2} \mathrm{~d}^{-1}$ \\
Col 4 & $91.7 \pm 8.7 \mathrm{~b}$ & $0.26 \pm 0.1 \mathrm{~b}$ & $0.64 \pm 0.07 \mathrm{a}$ & $204 \pm 57 \mathrm{~b}$ \\
Col 7 & $158.6 \pm 8.6 \mathrm{a}$ & $0.29 \pm 0.1 \mathrm{a}$ & $0.57 \pm 0.08 \mathrm{a}$ & $576 \pm 25 \mathrm{a}$ \\
Gto & $82.7 \pm 6.9 \mathrm{~b}$ & $0.27 \pm 0.1 \mathrm{~b}$ & $0.50 \pm 0.1 \mathrm{a}$ & $278 \pm 62 \mathrm{~b}$ \\
Jal & $169.6 \pm 11.2 \mathrm{a}$ & $0.28 \pm 0.1 \mathrm{ab}$ & $0.61 \pm 0.09 \mathrm{a}$ & $548 \pm 42 \mathrm{a}$ \\
SIGNIFICANCE & $* * *$ & $* * *$ & $* *$ & \\
HSD (Tukey test, 0.05) & 12.86 & 0.0012 & 0.14 & \\
* $^{* * *}$ and *** indicate $P<0.5,0.01$ and 0.001, respectively. & &
\end{tabular}

\section{Discussion}

Results of this study showed different variation patterns: no variation was observed in the $p s b A$ gene, whereas the ACCase gene showed more variation, indicating a different evolution history (pressure) for these genes. The ACCase gene is associated with herbicide resistance, and the polymorphism in the analyzed biotypes is associated with the selection pressure on weed populations in the "El Bajio" region in the central part of Mexico. The similarity between the suscep- 
tible individuals from this work and from Israel supports the idea that changes at the nucleotide and amino acid level in other biotypes is associated with resistance to herbicides. However, the nucleotide and amino acid mutations in different codons suggest that more than one selective event have occurred in the "El Bajio" region in the central part of Mexico. This might be associated with farmers' practices for weed management. A similar result in the ACCase gene has been documented by Délye (2005). Further, all mutations found in samples from the "El Bajio" region have been reported previously by Kaundun (2014) in grasses. For example, in the Gto biotype, a mutation in position 1,781 (Ile x Leu) was found and it has been reported to confer resistance to three chemical families (aryloxyphenoxypropionate, cyclohexanedione and phenylpyrazoline) (Powles \& Yu 2010). The use of chemical families of ACCase inhibitors, such as aryloxyphenoxypropionate and cyclohexanedione, is common in "El Bajio."

The polymorphism found in the ACCase inhibitor in the studied area shows that selective pressure from different herbicides could be underway because herbicide application is based on farmer's decision and this may have implications for weed management. The evolution of resistant populations in close geographic proximity possibly have evolved independently, as it has been observed in regions of Australia (Owen et al. 2011). Several studies have demonstrated the multiple genetic origins of herbicide resistance in crop areas; Délye et al. $(2004,2010)$ found that resistance to ACCase-inhibiting herbicides in populations of Alopecurus myosuroides in Europe (Germany, Belgium, France, Netherlands, United Kingdom and Turkey) had a different evolutionary origin because of different weed management programs in each country.

Moreover, changes in phenology, growth, biomass accumulation and fecundity were found among biotypes. Reductions in the biological cycle of the Gto and Col 4 biotypes were observed and might be related to selection pressure on life history components in these populations. Changes in phenology also have been observed as an evolutionary response to adapt to agroecosystems, mainly in relation to the timing of the crop cycle (Duke 1985, Weinig 2005, Kawecki 2008) and in response to the application of herbicides and other cultural practices (Mortimer 1997). These characteristics could be an indicator that the biotypes Col 4 and Gto, in addition of being resistant, are also adapted to agricultural practices. As suggested by Baker (1974), the reductions in life cycle and biomass represent adaptations to an ephemeral life cycle that ensures seed production. However, Grime (1979) indicated that weeds have evolved to adapt to sites with high productivity and disturbance, such as crop fields. These changes, along with control methods, such as crop rotation, changes in herbicide active ingredients and others, can change the dominance of resistant individuals in populations. Information regarding the life cycle of weeds can aid our understanding of population dynamics in the absence of the selection factor and the return of susceptibility in populations (Maxwell et al. 1990).

All of the results obtained from P. minor from "El Bajio" suggest the development of resistance, which could be the result of the use of more than one herbicide family, because more than one amino acid changed in a small geographic area; this also supports changes in phenology and biomass accumulation. The variation mosaic present in the zone suggests a diverse diversification pattern in resistance. Thus, it is important long term studies that help to understand the evolution of herbicides resistance in a context of population differentiation, variable management practices, gene flow, and landscape. This may help to develop strategies to reduce the use of herbicides (for instance, altering the application both temporally and spatially), and to increase yield.

\section{Acknowledgments}

The first author is grateful to CONACyT for a Ph.D. fellowship. The authors thank J. Antonio Tafoya Razo, who supplied the original seed that was used in this research.

\section{Literature cited}

Afentouli CG, Eleftherohorinos IG. 1996. Littleseed Canarygrass (Phalaris minor) and Short-spiked Canarygrass (Phalaris brachystachys) Interference in Wheat and Barley. Weed Science 44: 560-565.

Baker HG. 1974. The evolution of weeds. Annual Review of Ecology and Systematics 5: 1-24. DOI: 10.1146/annurev.es.05.110174.000245 
Baucom RS, Holt JS. 2009. Weeds of agricultural importance: bridging the gap between evolutionary ecology and crop and weed science. New Phytologist 184: 741-743. DOI: 10.1111/j.1469-8137.2009.03077.x

Cochran WG, Cox GM. 1990. Experimental designs. USA: John Willey and Sons.

Délye C, Michel S, Bérard A, Chauvel B, Brunel D, Guillemin JP, Dessaint F, Le Corre V. 2010. Geographical variation in resistance to acetyl-coenzyme A carboxylase-inhibiting herbicides across the range of the arable weed Alopecurus myosuroides (black-grass). New Phytologist 186: 1005-1017. DOI: $10.1111 / \mathrm{j} .1469-8137.2010 .03233 . x$

Délye C. 2005. Weed resistance to acetyl coenzyme A carboxylase inhibitors: an update. Weed Science 53: 728-746. DOI: 10.1614/WS-04-203R.1

Délye C, Michel S. 2005. 'Universal' primers for PCR-sequencing of grass chloroplastic acetyl-CoA carboxylase domains involved in resistance to herbicides. Weed Research 45: 323-330. DOI: 10.1111/ j.1365-3180.2005.00467.x

Délye C, Straub C, Michel S, Le Corre V. 2004. Nucleotide Variability at the Acetyl Coenzyme A Carboxylase Gene and the Signature of Herbicide Selection in the Grass Weed Alopecurus myosuroides (Huds.) Molecular Biology and Evolution 21: 884-892. DOI: 10.1093/molbev/msh095

Duke SO. 1985. Effects of herbicides on nonphotosynthetic process. In: Duke SO, ed. Weed Physiology Vol II Herbicide Physiology. Boca Raton: CRC Press, 91-112.

Forcella F, Banken KR. 1996. Relationships among Green Foxtail (Setaria viridis) seedling development, growing degree days, and time of nicosulfuron application. Weed Technology 10: 60-67.

García-Franco JL, Uscanga-Mortera E, Kohashi-Shibata J, García-Esteva A, Yáñez-Jiménez P, Ortega-Escobar HM. 2014. Caracterización morfológica de biotipos de Phalaris minor resistentes y susceptible a herbicidas inhibidores de la ACCasa. Botanical Sciences 92: 169-176. DOI: 10.17129/botsci.44

Grime JP. 1979. Plant strategies and vegetation processes. Chichester: Wiley.

Heap IM. 2016 International survey of herbicide-resistant weeds. <http://www.weedscience.org> (accessed August 2, 2016).

Hunt R. 1978. Plant growth analysis. London: Ed. Edward Arnold.

Kaundun SS. 2014. Resistance to acetyl-CoA carboxylase-inhibiting herbicides. Pest Management Science 70: 1405-1417. DOI: 10.1002/ps.3790

Kawecki TJ. 2008. Adaptation to Marginal Habitats. Annual Review of Ecology and Systematics 39: 321342. DOI: 10.1146/annurev.ecolsys.38.091206.095622

Maxwell BD, Roush ML, Radosevich SR. 1990. Predicting the evolution and dynamics of herbicide resistance in weed populations. Weed Technology 4: 2-13.

Mortimer AM. 1997. Phenological adaptation in weeds-an evolutionary response to the use of herbicides? Pest Management Science 51: 299-304. DOI: 10.1002/(SICI)1096-9063(199711)51:3<299::AIDPS653>3.0.CO;2-I

Owen MJ, Michael PJ, Renton M, Steadman KJ, Powles SB. 2011. Towards large-scale prediction of Lolium rigidum emergence. II. Correlation between dormancy and herbicide resistance levels suggests an impact of cropping systems. Weed Research 51: 133-141. DOI: 10.1111/j.1365-3180.2010.00835.x

Powles SB, Yu Q. 2010. Evolution in action: plants resistant to herbicides. Annual Review of Plant Biology 61: 317-347. DOI: 10.1146/annurev-arplant-042809-112119

Shukla V, 1996. Grasses of North-Eastern India. Jodhpur: Scientific Publishers.

Stewart Jr CN, Via LE. 1993. A rapid CTAB DNA isolation technique useful for RAPD fingerprinting and other PCR applications. Biotechniques 14: 748-749.

Tafoya JA, Morgado J. 2000. Resistencia de la maleza a la aplicación de herbicidas. Revista Mexicana de la Ciencia de la Maleza 46: 1-9.

Tal A, Kotoula-Syka E, Rubin B. 2000. Seed-bioassay to detect grass weeds resistant to acetyl coenzyme A carboxylase inhibiting herbicides. Crop Protection 19: 467-472. DOI: 10.1016/S0261-2194(00)00041-7

Tamura K, Stecher G, Peterson D, Filipski A, Kumar S. 2013. MEGA6: Molecular Evolutionary Genetics Analysis Version 6.0. Molecular Biology Evolution 30: 2725-2729. DOI: 10.1093/molbev/mst 197

Torres-García JR, Núñez-Farfán J, Uscanga-Mortera E, Trejo C, Conde-Martínez V, Kohashi-Shibata J, Martínez-Moreno D, Velazquéz-Marquez S. 2015a. Competition for canopy cover between accessions of Phalaris minor that are susceptible and resistant to ACCase inhibiting herbicides. Nordic Journal of Botany 33: 615-623. DOI: 10.1111/njb.00764

Torres-García JR, Uscanga-Mortera E, Trejo C, Conde-Martínez V, Kohashi-Shibata J, Núñez-Farfán J, Martínez-Moreno D. 2015b. Effect of herbicide resistance on the seed physiology of Phalaris minor (littleseed canarygrass). Botanical Sciences 93: 661-667. DOI: 10.17129/botsci.81

Untergasser A, Nijveen H, Rao X, Bisseling T, Geurts R, Leunissen JAM. 2007. Primer 3Plus an enhanced web interface to Primer3. Nucleic Acids Research 35: W71-W74. DOI: 10.1093/nar/gkm306

Weinig C. 2005. Rapid evolutionary responses to selection in heterogeneous environments among agricultural and nonagricultural weeds. International Journal of Plant Sciences 166: 641-647. DOI: $10.1086 / 429853$ 